\title{
Revealing the potential "master regulators" of pathogenesis in plants based on RNA-Seq data
}

Tsers I. ${ }^{1}$, Gorshkov V. ${ }^{1,2,3}$, Gogoleva N. ${ }^{1,2,3}$, Gogolev Y. ${ }^{1,2,3}$

${ }^{1}$ Federal Research Center "Kazan Scientific Center of Russian Academy of Sciences, Kazan, Russia; ${ }^{2}$ Kazan Institute of Biochemistry and Biophysics of Federal Research Center "Kazan Scientific Center of Russian Academy of Sciences, Kazan, Russia; ${ }^{3}$ Kazan Federal Univeristy, Kazan, Russia

E-mail: ivantsers@gmail.com

Key message. We propose an algorithm for RNA-Seq data analysis useful for revealing the "master regulators" of gene expression in experimental condition, as well as of cis-elements regulating transcript level of genes from certain groups.

Keywords: Transcriptomics, analysis of promoters, cis-elements

When analyzing plant transcriptomes, we aren't always able to explain the expression patterns of genes encoding similar proteins. The regulation of the expression of such genes may be explained through identifying certain cis-regulatory elements (CREs) in their promoters.

Aim. To develop an algorithm for correlating the expression patterns of differentially expressed genes (DEGs) with presence of binding sites for transcription factors (TF) of certain families within their promoters.

We compared transcriptomes of intact plants and plants infected with pectobacteria in order to reveal DEGs. For this, we were following standard pipeline for DE analysis. Using MapMan, KEGG and "manual" search, we split DEGs into functional categories. Using MAST, we searched CREs in the promoters of plant genes. Position weight motif matrices were obtained from PlantPAN3.0. To implement search of CREs that may be significant for the regulation of expression, we developed special scripts in $\mathrm{R}$ language. These scripts automatically compose a large number of DEGs samples according to the presence/absence of certain CREs in their promoters, rank the samples by size, test the significance of differences in expression between up- and down-regulated DEGs within samples. Finally, they render diagrams as the output of the analysis. We revealed 8606 DEGs in intact and infected plants. Around 2,3M CRE variants (that are binding sites for 999 different TFs) were found in promoters of plant genes. $18 \%$ of these CREs were located in promoters of DEGs. In some cases, pools of genes with specific CREs were enriched in DEGs. Among these CREs were those interacting with WRKY6, 42, 45, 51, 57 and TCP3, 15. The genes encoding the listed WRKYs (except for WRKY57) were up-regulated DEGs. These TFs are potential "master regulators" of infection. We also found that the presence of binding sites for WRKY (W-boxes) and for TCR transcription factors within the promoters of genes for chitinases significantly increases the probability for them to be upregulated during the infection. Similar patterns were found for a number of other DEG groups.

The study is supported by Ministry of Science and Higher Education of the Russian Federation (grant № 075-15-2019-1881).

Выявление потенциальных «мастер-регуляторов» фитопатогенеза на основе данных РНК-секвенирования Церс И.Д. ${ }^{1}$, Горшков В.Ю. ${ }^{1,2,3}$, Гоголева H.E. ${ }^{1,2,3}$, Гоголев Ю.В. ${ }^{1,2,3}$

${ }^{1}$ Федеральный исследовательский центр «Казанский научный центр Российской академии наук», Казань, Россия;

${ }^{2}$ Казанский институт биохимии и биофизики - обособленное структурное подразделение Федерального государственного бюджетного учреждения науки Федеральный исследовательский центр «Казанский научный центр Российской академии наук», Казань, Россия; ${ }^{3}$ Казанский Федеральный Университет, Казань, Россия

Аннотация. Предложен алгоритм анализа данных RNA-seq, позволяюший выявить «мастер-регуляторы» экспрессии генов в условиях эксперимента и ичс-элементы, наличие которых в промоторах группь генов определяет уровень их транскриптов.

Ключевые слова: транскриптомика, анализ промоторов, ичис-элементьл

При анализе транскриптомов растений не всегда удается объяснить наблюдаемый в условиях эксперимента характер экспрессии генов, кодирующих похожие белки, исходя из сходства первичных структур или функций этих белков. Регуляцию экспрессии таких генов можно объяснить путем выявления в их промоторных областях определенных цисэлементов (cis-regulatory elements, CRE), содержание которых может обуславливать наблюдаемые паттерны экспрессии.

Цель. Разработать алгоритм для поиска корреляций между характером экспрессии групп дифференциально экспрессирующихся генов (ДЭГ) и наличием в их промоторах сайтов связывания с транскрипционными факторами (ТФ), принадлежащими к определенным семействам.

Для выявления ДЭГ в интактных и инфицированных пектобактериями растениях мы сравнивали их транскриптомы, используя стандартный пайплайн. С помощью МapMan, KEGG и «ручного» поиска распределяли ДЭГ по функциональным категориям. Средствами MAST выполнили поиск CRE в промоторах генов растения (позиционные весовые матрицы мотивов для поиска загружены из PlantPAN3.0). CRE, значимые для регуляции экспрессии, мы искали с помощью специально написанных нами на языке $\mathrm{R}$ скриптов. Они автоматически составляют множество выборок ДЭГ по критерию наличия/отсутствия определенных CRE, ранжируют их по размеру и составу, тестируют достоверность различия экспрессии внутри них, представляют результат анализа в виде диаграмм.

В интактных и инфицированных растениях мы выявили 8606 ДЭГ. В промоторах генов растения найдено 2,3 млн вариантов CRE, которые являются сайтами связывания для 999 различных ТФ. Из этих СRE 18\% расположены в промоторах ДЭГ. Несколько групп генов, содержащих определенные CRE, были насыщенны ДЭГ. Это пулы генов, которые имеют CRE, связывающие ТФ: WRKY6, 42, 45, 51, 57 и TCP3, 15. Гены, кодирующие перечисленные WRKY (кроме WRKY57), были ДЭГ с повышенным уровнем экспрессии. Эти ТФ - потенциальные «мастер-регуляторы» развития инфекции. Мы также обнаружили, что присутствие сайтов связывания с WRKY в промоторах генов хитиназ увеличивает вероятность усиления их экспрессии при инфекции; аналогичные закономерности обнаружили для ряда других групп ДЭГ. Работа поддержана грантом Министерства науки и высшего образования РФ № 075-15-2019-1881. 